\title{
RETHINKING KONSEP NUSYUZ RELASI MENCIPTAKAN HARMONISASI DALAM KELUARGA
}

\author{
Moh. Subhan, M.E.I \\ STAI MU Pamekasan \\ orsatpmk@gmail.com
}

\begin{abstract}
A basic concept of a house hold is the creation of a happy and prosperous family. This condition is achieved when the relationship between the couple harmony, but in reality the relationship is not seldom compatible. Disharmony in the family is caused by several factors, including the act of disobedience or iniquity by husband and wife in fulfilling their duty (nusuz). Nusyuz $z$ varied factors; One party's uneasiness over the other's behavior, a demand which exceeds the reasonable limit of one party against the other, and so on.

Nusyuz has been identified as the wife's insubordination to the husband, so it's as if nusyuz never happened to the husband. While this circumstance often makes a husband commit ACTS of violence against his wife, so it's very important for us to re-understand -- rethinking - of the nusyuz concept, so that it will engender (menimbulkan) awareness and a sense of responsibility between the husband and wife who at the end create(menciptakan) family harmonization.
\end{abstract}

Key words: Nusyuz, relation, rethinking, harmonization.

\begin{abstract}
ABSTRAK
Konsep dasar dalam berumah tangga adalah terbentuknya keluarga yang bahagia dan sejahtera. Keadaan seperti itu akan tercapai jika relasi antara suami isteri berjalan harmonis, tetapi dalam kenyataannya tidak jarang hubungan antara keduanya tidak harmonis. Ketidak harmonisan hubungan dalam keluarga disebabkan oleh beberapa fakror, diantaranya adalah ketidaktaatan atau kedurhakaan baik oleh suami maupun isteri dalam memenuhi kewajibannya (nusyuz). Faktor terjadinya nusyuz sangat beragam; mulai dari ketidak nyamanan salah satu pihak atas perilaku pihak lain, adanya tuntutan yang melampaui batas kewajaran dari salah satu pihak terhadap pihak yang lain, dan sebagainya.

Nusyuz selama ini selalu diidentikkan sebagai pembangkangan istri terhadap suami, sehingga seakan-akan nusyuz tidak pernah terjadi pada suami. Keadaan yang seperti ini seringkali menjadikan suami melakukan tindakan kekerasan tehadap istri, maka disini sangat penting untuk melakukan pemahaman ulang -rethinking-, terhadap konsep nusyuz, sehingga akan melahirkan kesadaran dan rasa tanggung jawab yang utuh antara suami dan isteri yang pada ending nya melahirkan harmonisasi dalam keluarga.
\end{abstract}

Kata Kunci: Nusyuz, relasi, rethinking, harmonisasi.

\section{PENDAHULUAN}

Semua makhluk hidup di dunia ini diciptakan oleh Allah dengan berpasangpasangan dengan tujuan agar bisa berkembang biak, sehingga spisies makhluk hidup tersebut bisa tetap eksis, demikian juga dengan manusia. Manusia diciptakan oleh Allah dengan beragam etnis dan warga negara agar mereka saling memafhumi, membantu untuk melengkapi keinginan dan kebutuhannya, termasuk didalamnya kebutuhan 
bilogis. Melalui lembaga perkawinan, maka kebutuhan biologis manusia dapat disalurkan secara benar dan halal. Pernikahan dalam Islam tidak hanya sekedar hubungan bilogis semata, tetapi lebih dari itu pernikahan dalam Islam merupakan ajaran yang bernilai ibadah. Sehingga segala bentuk aktivitas yang dikerjakan oleh suami dan isteri dalam pemenuhan hak dan kewajibannya berdimensi ibadah.

Tujuan pernikahan dalam Islam adalah terbentuknya sebuah keluarga yang makmur, diliputi rasa syukur dan mahabbah dengan mahkota keimanan dan ketaqwaan. Pernikahan merupakan salah satu sunnah Rasulullah dan sebagai salah satu bentuk ketaatan kepada Allah, sebagaimana dalam QS. 30:21. Statemen serupa kita temukan pada kandungan pasal 1 Undang-Undang Perkawinan Nomor 1 Tahun 1974, dimana hakikat dilaksanakan pernikahan berdasarkan pada aturan Allah adalah terciptanya keluarga yang makmur dan langgeng. Sementara pada KHI Ps 3 juga dinyatakan bahwa pernikahan dilaksanakan dengan maksud terwujudnya kehidupan rumah tangga yang sakînah, mawaddah dan rahmah".

Hak dan kewajiban suami dan isteri dalam hidup berumah tangga bersifat balance tanpa ada yang diunggulkan salah satunya, sebagaimana statement Murthada Muthari. ${ }^{1}$ Kehidupan suami isteri dalam berumah tangga harus didasarkan pada bangunan relasi komunikasi yang efektif melalui sikap saling memahami, menghargai, menghormati, dan saling memenuhi kebutuhan masing-masing secara penuh tanggung jawab. Jika salah satu pihak melalaikan tugas dan kewajibannya, maka sudah dapat dipastikan akan terjadi berbagai problem rumah tangga seperti kesalahpahaman, perseteruan secara terusmenerus (syiqoq), dan ketegangan yang bisa berdampak pada rapuhnya bangunan keharmonisan rumah tangga. Oleh karena itu, masing-masing pihak harus saling menjaga sikap dan perilaku dalam rumah tangga.

Akan tetapi dalam relasi hidup bersama antara suami isteri tidak bisa dipungkiri munculnya bebagai macam konflik, baik ditimbulkan oleh pihak istri maupun suami atau bahkan dari pihak ketiga. Indikasi sebagai penyebab terjadinya konflik dalam rumah tangga adalah oleh kurangnya saling pengertian dan kurangnya saling memahami antara suami isteri, sehingga menimbulkan pembangkangan atau keengganan melaksanakan

${ }^{1}$ Zaitunah Subhan, Tafsir Kebencian: Studi Bias Gender dalam Tafsir Al-Qur`ān, Cet. 1, (Yogyakarta: LKiS, 1999), 134-135. 
sesuatu yang menjadi kewajibannya dan menjadi hak bagi yang lainnya. Dalam Islam, bentuk pembangkangan atau keengganan tersebut disebut dengan nusyuz, ( gambul=bahasa madura, purhek=bahasa jawa).

Jika antara suami dan isteri sejak awal telah membangun relasi rumah tangga yang didasari oleh syariat Islam dengan saling memahami kedudukan masing-masing, maka tidak akan berakibat terhadap pembangkangan dan permusuhan yang berkelanjutan. Oleh karena itu, harus disadari bahwa seorang laki-laki yang telah membuat perjanjian atas nama Allah untuk menjadikan seorang perempuan sebagai istrinya, merupakan perjanjian yang tidak main-main. Oleh karena itu, hidup bersama sebagai suami istri dalam berumah tangga harus selalu berpijak pada aturan-aturan Allah dan Rasulullah, sehingga ikatan yang telah dibuat, bukan hanya sekedar perjanjian yang berdimensi sosial ansich, yaitu ikatan yang terjadi antara suami dengan wali, keluarga dari pihak isteri secara keseluruhan dan dengan isteri sendiri, akan tetapi suatu bentuk perjanjian yang berdimensi aqidah dan ubudiyah yang langsung berjanji dengan Rabbul izzati.

Sampai sekarang persoalan nusyuz masih tetap menjadi polemik tersendiri pada masyarakat muslim, sebab sebagian ulama menyatakan bahwa nuzus hanya terjadi pada wanita/isteri, sementara ulama yang lain menyatakan, nuzus bisa saja terjadi pada siapapun, baik pihak suami maupun pihak isteri. Karenanya, agar nusyuz dapat dipahami secara proporsional dan konsepsional, maka perlu upaya rethinking terhadap konsep nuzus itu sendiri. Tulisan ini akan mencoba untuk mengurai tentang konsepsi nusyuz , cara penanganannya dan akibat hukum yang ditimbulkan.

\section{NORMATIVITAS NUSYUZ DALAM AL QUR'AN}

Secara etimologi nusyuz bermakna irtifa' (bangkit, menonjolkan dan meninggikan diri), artinya kedurhakaan yang dilakukan isteri kepada suaminya. ${ }^{2}$ Sedangkan Ibnu Manzur mendefinisikan nusyuz dengan tempat yang menonjol dari bumi. ${ }^{3}$ Sementara Imam Ath Thobari memaknai nusyuz dengan kedurhakaan dan pembangkangan. ${ }^{4}$

\footnotetext{
${ }^{2}$ Slamet Abidin dan Aminuddin, Fiqh Munakahat, jilid 1\&2, (Bandung, Pustaka Setia, 1999), 185.

${ }^{3}$ Ibn Manzur, Lisan al-Arab, (Kairo: Dar al-Ma"earif, t.th), 4425.

${ }^{4}$ Thobari, Tafsir Ath-Thabari, Juz 8, (Jakarta, Pustaka Azzam,. 2008), 300.
} 
Nusyuz dalam pengetian terminologi mempunyai beberapa makna, sebagaimana yang dikemumakan oleh beberapa ulama. Ulama Hanafiyah memberi batasan, bahwa nusyuz adalah keluarnya isteri dari rumah suami dengan cara yang tidak dibenarkan oleh syara'. Kelompok ulama Malikiyah memberi makna, bahwa nusyuz adalah perilaku suami-isteri yang saling berbuat aniaya. Ulama Syafi'iyah dan Hanabilah memberi makna dengan perselisihan yang terjadi antara suami-isteri. Pendapat Imam Jalaluddin Al-Mahalli dan Jalaluddin As-Suyuthi dalam kitabnya Tafsir Jalalain bahwa makna "nusyuz adalah pembangkangan isteri terhadap kewajibannya pada suami." 5 Sementara Sayyid Sabiq mendefinisikan nusyuz sebagai "pembangkangan istri pada suami, ketidak patuhan atau menolak diajak ke tempat tidurnya atau keluar rumah tanpa seizin suaminya."6

Setelah memperhatikan beberapa definisi sebagaimana telah dinyatakan oleh beberapa ulama, dapat ditarik konklusi bahwa nusyuz adalah pembangkangan atau kedurhakaan salah satu pihak baik suami maupun istri dalam memenuhi kewajibannya dalam berumah tangga. Sedangkan konsepsi nusyuz dalam al-Quran dapat ditemukan dalam beberapa surat dan ayat dengan beberapa variannya. Dalam varian isim masdhar sebagaimana terdapat dalam QS. 58; 11, dalam bentuk fiil mudhori' yang bersambung dengan dhomir mutakallim ma'a al-ghoir, terdapat pada QS. 2; 259, dan dalam bentuk mashdar pada QS. 4; 34 dan 127.7

Setelah memperhatikan dan menelaah penggalan ayat dan empat surat al Qur'an tersebut maka didapatkan satu konsep pemahaman, nusyuz adalah tidak responsifnya salah satu pasangan baik suami atau isteri terhadap hak dan kewajiban dalam hidup berumah tangga yang berakibat pada ketidak harmonisan relasi sebagai suami isteri. Kondisi tersebut diindikasikan dengan beberapa indikasi; pertama, QS. 58; $11,{ }^{8}$ Dalam surat tersebut term nusyuz dikaitkan dengan akhlak mendatangi majelis Rasulullah, dimana para audien harus sama-sama menjaga ketertiban dan ketenangan majelis

\footnotetext{
${ }^{5}$ Jalaluddin al-Mahalliy dan Jalaluddin as-Suyuthi. Tafsir Jalalain, Juz. I (Dar al-Ihya' al-Kutub AlArabiyyah Indonesia,tt), 76.

${ }^{6}$ Sayyid Sabiq, Fiqh Sunnah, Jilid II, (Madinah: Al-Fatkh Li I'laamil Araby, 1990), 314.

${ }^{7}$ Muhammad Fuad Abdul Baqi, Al-Mu'jamul Mufahras li alfadz al-Quran al-Karim (Bandung: CV. Diponegoro, T.th), 873.

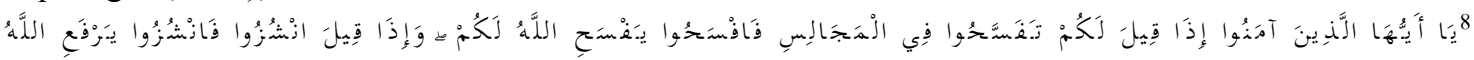

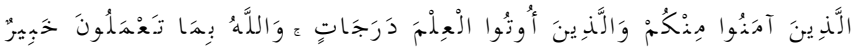


tersebut dengan cara saling berlapang dada dan tidak mengabaikan hak-hak pihak lain yang ada di majelis tersebut serta berdiri sebagai perhormatan terhadap Rasulullah.

Tindakan seperti itu sudah pasti dilakukan dengan penuh kesadaran sebagai bukti pengagungan yang sangat tinggi kepada rasulullah. Keadaan seperti itu, apabila dikorelasikan dengan perilaku nusyuz dalam hidup berumah tangga, dapat dikatakan bahwa tindakan pembangkangan yang diperbuat suami atau isteri terhadap hak dan kewajiban, baru bisa dinyatakan sebagai nusyuz apabila dilakukan dalam keadaan sadar dan ada niat tertentu, seperti adanya maksud untuk berakhirnya ikatan sebagai suami isteri dengan cara melakukan perselingkuhan yang dilakukan secara sadar.

Kedua, QS 2; 259, ${ }^{9}$ Dimana ayat ini membincang tentang kekuasaan Allah yang meliputi terhadap semua makhluknya tanpa terkecuali. Allah ingin menunjukkan atas keraguan yang menyelimuti Raja Namruj dan kaumnya, dimana dia dan para kaumnya membanath dan tidak mempercayai ucapan nabiyullah Ibrahim bahwa Allah adalah dzat yang kuasa untuk menghidupkan dan mematikan semua ciptaan-Nya. Sebagai hujjah bahwa Allah adalah dzat yang Maha Kuasa, maka dipertontonkanlah suatu kejadian di luar nalar logika kepada Namruj dan pengikutnya melalui nabiyullah Ibrahim, dengan menyatukan kembali tulang-tulang yang telah hancur menjadi burung yang hidup. Disini Allah ingin menunjukkan Kekuasaan-Nya terhadap segala hal dan sekaligus sebagai penghinaan terhadap kesombongan Namruj. Peristiwa tersebut, jika dibawa ke dalam ranah nusyuz, maka yang dikatakan tindakan nusyuz adalah manakala suami ataupun istri melakukan perbuatan yang bertujuan untuk merendahkan martabat pihak lain.

Ketiga, QS. 4; 34, ${ }^{10}$ bahwa indikasi nusyuznya seorang istri dapat diketahui dari dua hal. Pertama, isteri merasa derajatnya melebihi suaminya, sehingga ia tidak

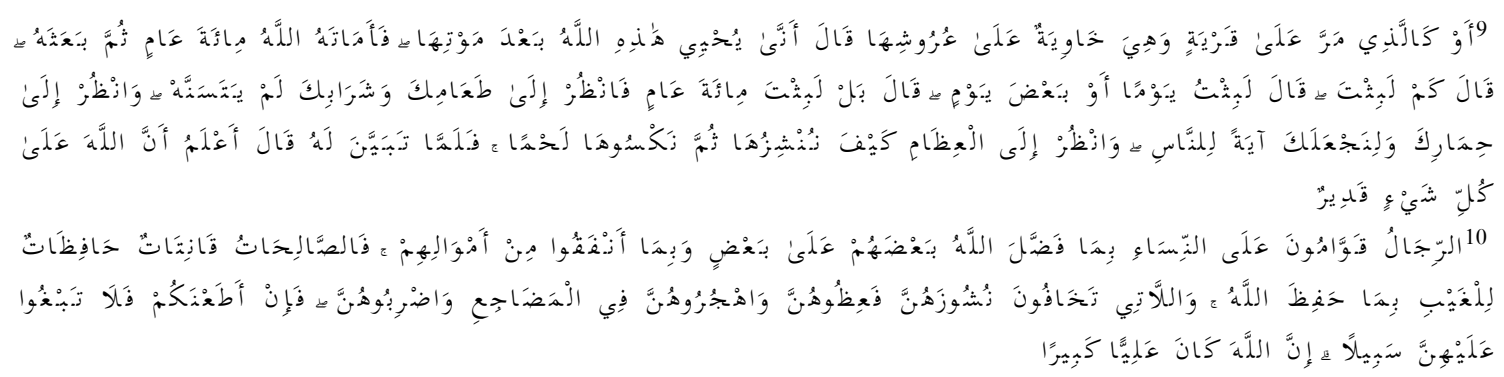

Asbabun Nuzul ayat 34 surat anNisa' adalah terkait dengan perilaku nusyuz yang dilakukan oleh seorang wanita pada zaman Rasulllah yang bernama Habībah binti Zaid bin Abi Zuhair, salah satu istri dari sahabat kaum Anshar yang menceritakan kepada Rasulullah bahwa ia telah dipukul oleh suaminya yaitu Saad bin 
melaksanakan kewajibannya sebagai seorang isteri. Keadaan seperti ini rentan terhadap pembangkangan sikap isteri terhadap perintah suami, karena isteri meremehkan suaminya. Kedua, berpaling dan membenci suami, sehingga relasi suami isteri dalam keluarga tidak harmonis. Menurut mufassir Ibnu Katsir, bahwa nusyuz adalah merasa lebih tinggi. Artinya wanita dikatakan nusyuz manakala dia angkuh atau sombong kepada suaminya, sehingga dia berpaling dan membenci suaminya dan tidak menjalankan semua kewajibannya sebagai isteri. Manakala tanda-tanda nusyuz sudah nampak pada isteri, maka kewajiban suami untuk menasehatinya serta menakut-nakuti dengan siksa Allah yang pedih. Karena Allah telah mewajibkan kepada suami atas isteri, dengan ketaatan isteri kepada suami, serta mengharamkan maksiat kepadanya, karena keutamaan dan kelebihan yang dimiliki oleh suami atas isteri. ${ }^{11}$

Keempat, Dalam penafsiran imam as-Suyuti pada surat an-Nisa'ayat $128,{ }^{12}$ dimana timbulnya tindakan nusyuz tidak hanya dari pihak isteri, tetapi bisa juga timbul dari pihak suami, sehingga seorang suami dikatakan nusyuz manakala ia lalai dalam memenuhi kewajiban nafkah kepada istrinya baik nafkah jasmani maupun nafkah rohani. Dan ayat 128 surat an Nisa' ini dapat dikembangkan lebih jauh lagi dengan mengkorelasikan dengan ayat 34 pada surat yang sama. Dimana pada ayat 34 dinyatakan dengan tegas, bahwa pemimpin dalam rumah tangga adalah suami. Oleh karena iitu, ketidak berhasilan seorang suami dalam membina keluarga (memimpin isteri untuk bertambah iman dan takwanya), dikatakan sebagai perbuatan nusyuz, sebab suami dianggap tidak mampu melaksanakan tanggung jawab yang telah diamanatkan oleh Allah. Disamping itu, tindakan suami dengan mencari-cari kesalahan istri adalah termasuk kategori tindakan nusyuz.

al- Rabi. Saat itu Rasulullah memperbolehkan untuk menghukum qishos suaminya, kemudian turun wahyu untuk memberikan tanggapan dari jawaban Nabi atas penangguh hukuman qisas.

${ }^{11}$ Abdullah bin Muhammad bin 'Abdurrahman bin Ishaq Alu Syaikh, 2004. Tafsir Ibnu Katsir Jilid 2 terj. Abdul Ghoffar E.M. (Bogor: Pustaka Imam Asy-Syafi’ I, 2004), 73.

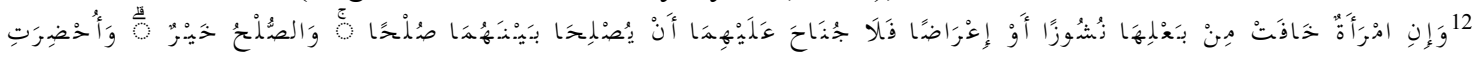

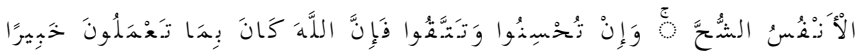

Dan jika seorang wanita khawatir akan nusyuz atau sikap tidak acuh dari suaminya, maka tidak mengapa bagi keduanya mengadakan perdamaian yang sebenar-benarnya, dan perdamaian itu lebih baik (bagi mereka) walaupun manusia itu menurut tabiatnya kikir. Dan jika kamu bergaul dengan isterimu secara baik dan memelihara dirimu (dari nusyuz dan sikap tak acuh), maka sesungguhnya Allah adalah Maha Mengetahui apa yang kamu kerjakan. 


\section{BENTUK-BENTUK NUSYUZ DAN PENYEBABNYA}

Nusyuz adalah bagian terkecil dari problem rumah tangga. Problem dalam rumah tangga disebabkan oleh beberapa faktor seperti adanya persepsi yang berbeda, pinsip yang berbeda dan adanya kepentingan yang berbeda dari masing-masing pihak. ${ }^{13}$ Begitu juga terjadinya nusyuz, banyak faktor yang mempengaruhi terjadinya perbuatan nusyuz dalam hidup rumah tangga.

Berdasarkan pada ayat-ayat tentang nusyuz yang telah disebutkan di atas, bahwa faktor penyebab terjadinya tindakan nusyuz dalam perspektif al Qur'an disebabkan oleh beberapa faktor.. Pertama, adalah Asy-Syuhha yang dimaknai oleh para mufassir dengan sifat pelit tingkat akut. ${ }^{14}$ Jika hal tersebut ditarik ke dalam ranah hidup berumah tangga, pelit dianggap sebagai salah satu faktor pemicu terjadinya nusyuz. Sifat pelit dalam konteks ini bisa dilihat dari dua sudut pandang, yaitu pelit dalam hal materi dan pelit dalam hal non materi. Pelit dalam hal materi berkaitan dengan sikap suami yang enggan dan lalai memberikan nafkah kepada istrinya. Sementara pelit dalam non materi adalah sikap acuh tak acuh pada pasangannya. Sikap acuh tak acuh ini bisa saja terjadi pada kedua belah pasangan, baik suami maupun isteri. Jika kondisi ini sudah ada dalam rumah tangga, maka sikap dewasa sangat dituntut kepada kedua belah pihak untuk segera introspeksi diri dan menjauhkan sikap egois dengan mengedepankan sikap toleransi dan saling percaya, agar prolem rumah tangga yang mengarah ke nusyuz segera dapat diatasi.

Faktor kedua, terjadinya nusyuz dalam perspektif al Qur'an adalah sifat dengki, dimana seseorang merasa resah terhadap kelebihan yang dimiliki orang lain, sebagaimana difirmankan Allah dalam QS. 4; 32. Dalam ayat tersebut Allah melarang seseorang berangan-angan di luar kemampuan rielnya. Apabila ayat tersebut dikorelasikan dengan konteks relasi suami dan istri dalam kehidupan berumah tangga, maka larangan tersebut ditujukan kepada suami isteri agar keduanya tidak saling dengki terhadap hak dan kewajiban yang telah ditetapkan Allah atas mereka berdua dan dalam menjalankan hak dan kewajibannya agar dilaksanakan dengan tulus dan ihlas. Karena apapun yang telah ditetapkan Allah kepada suami isteri dalam hidup berumah tangga

\footnotetext{
${ }^{13}$ J. Dwi Narwoko dan Bagong Suyanto, Sosiologi: TeksPengantar dan Terapan (Jakarta: Kencana, 2007), 68.

${ }^{14}$ Pelit/kikir adalah sifat yang terlampau hemat dalam mengeluarkan harta bendanya. Lihat pada Kamus Bahasa Indonesia, 699.
} 
sudah disesuaikan dengan kodrat dan kemampuan masing-masing. Oleh sebab itu, baik suami ataupun isteri harus selalu senantiasa memohon maunah kepada Allah supaya diberi kemampuan dan keseriusan agar mampu melaksanakan tugas dan kewajiban tersebut sebagai suatu amanah.

Faktor Ketiga, penyebab terjadinya nusyuz adalah adanya situasi tertentu, dimana dalam suatu keluarga munculnya pihak ketiga baik dari keluarga isteri maupun suami yang menjadi pemicu munculnya konflik dalam rumah tangga, atau adanya keinginan dari isteri untuk bekerja di luar rumah dengan maksud agar derajat kedudukannya lebih tinggi dari suaminya, sehingga ia tidak bisa diperintah-perintah oleh suaminya. Kondisi dimana isteri merasa lebih tinggi derajatnya dari suami akan mudah terjadi kedurhakaan dan pembangkangan isteri terhadap perintah suami. Kemungkinan faktor lain adalah kesibukan dari suami isteri bekerja di luar rumah, sehingga mereka jarang ketemu dan jarang komunikasi, masing-masing asyik dengan urusannya sendirisendiri. Rumah seakan-akan hanya dijadikan tempat tidur dan pulang melepas lelah. Kondisi seperti itu jika dibiarkan berlarut-larut dan tanpa ada penyelesaian bersama, maka pada saatnya akan berdampak terhadap tidak berfungsinya keluarga sebagai fungsi afektif, ${ }^{15}$ reproduksi ${ }^{16}$ dan sosialisasi. ${ }^{17}$

Selama ini konotasi nusyuz selalu diidentikkan dengan kedurhakaan istri terhadap suami, sebagaimana terdapat dalam KHI Ps. 84, yang hanya mengatur nusyuz dari pihak istri. ${ }^{18}$ Padahal al Qur'an telah menyatakan dengan jelas, bahwa nusyuz bisa saja terjadi pada isteri maupun suami. Abu Mansur al-Lugawi menyatakan bahwa suami

\footnotetext{
${ }^{15}$ Fungsi internal keluarga sebagai dasar kekuatan keluarga yang meliputi sikap saling menyayangi, saling memberi motivasi dan semangat dan saling toleran diantara sesama anggota keluarga.

${ }^{16}$ Fungsi keluarga dalam melanjutkan keberlangsungan keturunan dan menambah meningkatkan sumber daya insani.

${ }^{17}$ Fungsi untuk menjaga keberlangsungan proses interaksi dari semua anggota keluarga dalam keluarga.

${ }^{18}$ Pasal 84

(1) Isteri dapat dianggap nusyuz jika ia tidak mau melaksanakan kewajiban-kewajiban sebagaimana dimaksud dalam pasal 83 ayat (1) kecuali dengan alasan yang sah

(2) Selama isteri dalam nusyuz, kewajiban suami terhadap isterinya tersebut pada pasal 80 ayat (4) huruf a dan b tidak berlaku kecuali hal-hal untuk kepentingan anaknya.

(3) Kewajiban suami tersebut pada ayat (2) di atas berlaku kembali sesuadah isteri nusyuz

(4) Ketentuan tentang ada atau tidak adanya nusyuz dari isteri harus didasarkan atas bukti yang sah.
} 
isteri mempunyai potensi yang sama untuk melakukan nusuz, ${ }^{19}$ dan bentuk tindakan nusyuz bisa berupa perbuatan dan perkataan.

Bentuk nusyuz dari pihak isteri yang berupa perbuatan seperti; pertama, isteri tidak mematuhi dan mentaati perintah suaminya. Dalam keadaan tertentu isteri diperbolehkan tidak mentaati perintah suami, manakala perintah tersebut berkaitan dengan melakukan tindakan yang dilarang oleh agama. Sehingga harus dipahami terlebih dahulu faktor penyebab ketidak taatan isteri pada perintah suami.

Kedua, keluarnya isteri dari tempat tinggal bersama tanpa seizin suaminya dan, atau tanpa alasan yang diperbolehan oleh syariat, tetapi jika keluarnya isteri dari tempat tinggal bersama karena ada hubungannya untuk menyempurnakan tugas dan kewajibannya sebagai ibu rumah tangga, seperti belanja di supermaket untuk kebutuhan keluarga, atau membelikan baju seragam sekolah anak-anaknya, maka keluarnya istri dari rumah suaminya dalam keadaan seperti itu, meskipun tanpa seizin suaminya, tidak bisa dikatakan sebagai perbuatan nusyuz, sebab dalam kasus tersebut ada suatu hal yang bersifat dharuriyah terkait dengan keberlangsungan kehidupan dalam keluarga. ${ }^{20}$

Ketiga, keengganan isteri untuk pindah ke tempat tinggal yang telah disediakan oleh suaminya. Sikap isteri seperti itu, tidak serta merta langsung dihukumi sebagai tindakan nusyuz, sebab ketidak mauan isteri pindah ke tempat tinggal yang telah disediakan suami kemungkinan ada faktor-faktor tertentu, seperti traumatis terhadap lokasi dimana rumah tersebut berada. Dalam keadaan demikian, maka suami harus bersikap bijak, dengan sikap isteri tersebut. Tindakan isteri baru dikatakan nusyuz manakala ia tidak mau pindah ke tempat tinggal yang telah disediakan suaminya tanpa adanya alasan yang dibenarkan oleh agama.

Keempat, sikap egois dan kesewang-wenangan isteri terhadap suami, karena suami tinggal di rumah isteri atas izin dan keinginan isteri. Sikap tersebut muncul karena isteri merasa lebih punya kuasa daripada suaminya, karena stat us suami hanya numpang di rumah isteri. Keadaan seperti ini lazimya dialami oleh mereka yang baru membina rumah tangga dan suami belum mampu menyediakan tempat tinggal untuk isterinya.

\footnotetext{
${ }^{19}$ Abu Abdillah bin Ahmad al-Qurtubi, Al-Jami'i ahkam al-Qur'an, Juz, III, (Bairut, Dar al-Fikr, T.th), 150 .

${ }^{20}$ Imam Taqiyuddin Abu Bakr ibn Muhammad al-Husain ad-Dimasyqi, Kifayat al-Akhyar, Juz, II, (Beirut, Dar al Kitab al Ilmiyah, 1995), 148
} 
Kelima, ketidak mauan isteri menuruti keinginan suami untuk melakukan hubungan seksual, atau isteri tidak segera melakukan perintah suami dan tidak segera merespon ketika suami memanggilnya untuk melakukan hubungan seksual. Pemahaman yang harus dibangun dalam persoalan ini adalah, bahwa keengganan isteri melakukan hubungan seksual dan koitus dengan suami bukan disebabkan karena adanya udzur syari' $i$, seperti isteri dalam keadaan kurang sehat.

Keenam, Terjadinya perubahan sikap isteri dari baik menjadi buruk, dari lembut menjadi kasar. Dalam hal ini, suami sebagai kepala rumah tangga harus menyikapinya dengan penuh kearifan dan kebijakan, tidak gegabah menuduh isteri telah nusyuz. Perubahan sikap pada isteri sudah barang tentu ada faktor penyebabnya, bisa dari faktor internal atau faktor internal. Faktor-faktor tersebut harus mampu diketahui oleh suami, sehingga dia cepat dan tepat dalam mengatasi perubahan sikap isteri tersebut.

Ketujuh, isteri saat berkomunikasi dengan suami menggunakan logat yang kasar, atau isteri pada waktu menjawab pertanyaan suami memakai suara dengan nada tinggi. Sikap dewasa dalam hal ini benar-benar menjadi taruhan keberlangsungan rumah tangga suami isteri. Batasan dari suara keras dan tinggi dalam hal ini, bukan karena tabiat, tetapi karena faktor lain yang membuat isteri bersuara tinggi dan kasar pada suami. Jika suara isteri kasar dan keras disebabkan karena tabiat, maka dalam hal ini suami harus mampu merubah isteri berkata dan berkomunikasi yang lembut. dari cara bertutur kata atau cara menjawab panggilan suami,dan hal tersebut bukan bagian dari nusyuz.

Kedelapan, isteri melakukan kekerasan verbal ${ }^{21}$ pada suami. seperti isteri mengumpat atau memaki suami dengan kalimat yang keji (dasar kamu anjing, biadab), atau melecehkan kemampuan suami (kamu suami yang tidak berguna), dsb.

Kesembilan, isteri bermuram durja dan berpaling dari suaminya. Raut muka bisa menjadi cerminan kondisi rohani seseorang, jika raut muka seseorang berseri-seri menunjukkan bahwa rohani orang tersebut sedang bahagia, dan begitu pula sebaliknya. Perempuan solihah adalah mereka ketika dipandang oleh suaminya dapat

\footnotetext{
${ }^{21}$ Kekerasan yang tertuju pada perasaan seseorang, sehingga orang tersebut merasa tertekan atau terhina.
} 
menyenangkannya. Keadaan seperti ini bisa terjadi manakala wajah isteri berseri-seri (malihul wajhi). ${ }^{22}$

Sedangkan nusyuz pada suami terjadi manakala ia melakukan kedurhakaan kepada Allah dan rasul-Nya karena tidak melaksanakan kewajibannya terhadap isterinya dengan patut. Dalam praktiknya nusyusnya suami bisa berupa perkataan, perbuatan atau gabungan dari kedua-duanya. Bentuk-bentuk nusyuz pada suami diantaranya:

Pertama, kesengajaan suami dengan tidak memberi nafkah pada isterinya, baik berupa nafkah bathin atau nafkah lahir, padahal ia tahu dan ia mampu untuk menafkahinya. Salah satu orang yang akan mendapat laknat dan siksa yang pedih dari Allah nanti pada hari kiyamat adalah seorang suami yang menyia-nyiakan atau menterlantarkan keluarganya dengan sengaja. Dan seorang isteri akan dapat masuk surga karena kesabarannya, atas ketidak mampuan suaminya memberi nafkah yang patut.

Kedua, suami tidak memperlakukan isteri dengan baik dan layak. Suami sering berbuat kasar pada isteri, seperti menyakiti fisik dan mental isteri, kasar dan egois dalam menjalankan hubungan seksual dan perbuatan lain yang bertentangan dengan prinsip pergaulan baik (muasyarah bil ma'ruf). ${ }^{23}$ Isteri merupakan amanah dari orang tua yang harus dijaga dan dilaksanakan. Apabila seorang wanita telah menikah maka pengabdiannya selain kepada Allah dan rasulullah adalah suaminya, bukan kepada orang tuanya. Jadi pada saat akad nikah, sebenarnya telah terjadi pelimpahan amanah (tanggung jawab) dari orang tua mempelai wanita kepada menant unya (suami). Menjaga dan melaksanakan amanah orang tua, sama halnya dengan melaksanakan amanah Allah dan rasul-Nya.

Ketiga, dalam diri suami muncul rasa tidak sayang terhadap isteri, sehingga sikap suami tidak lagi memperpedulikan dan empati terhadap isteri, bahkan lambat laun sikap suami tersebut berubah menjadi kebencian.

Keempat, suami mengusir isteri keluar dari tempat tinggal bersama tanpa alasan yang sah. Rumah bagi seorang isteri adalah tempat untuk berlindung dari bahaya dan fitnah. Bahkan jika sangat terpaksa, sebaiknya suami yang keluar dari rumah daripada

\footnotetext{
${ }^{22}$ Achmad Furqan Darajat, Tipologi Relasi Suami Isteri dan Indikator Terjadinya Nusyuz Tafaqquh: Jurnal Hukum Ekonomi Syariah dan Ahawl as Syahsiyah, 57.

${ }^{23}$ Amir Syarifuddin, Hukum Perkawinan Islam di Indonesia, Antara Fiqh Munakahat dan Undang-Undang Perkawinan, (Jakarta: Kencana. 2006), 193.
} 
isteri. Sebab resiko yang dihadapi jauh lebih kecil, bila dibanding isteri yang keluar dari rumah. Bahkan dalam QS. 65; 1 dinyatakan suami dilarang mengusir isteri, meskipun isteri sudah ditalak.

Kelima, suami tidak mau melunasi mahar yang belum dibayar sewaktu melaksanakan akad nikah. Padahal mahar adalah hak mutlak isteri yang wajib dibayar oleh suami, sebagaimana dinyatakan dalam QS. 4;4, ${ }^{24}$ atau suami mengambil kembali secara paksa mahar yang telah diberikan kepada isterinya. Hal tersebut merupakan tindakan yang sangat tercela, karena bertentangan dengan ajaran Islam. Asy Syafi'i dan An Nakha,i berpendapat, bahwa suami isteri diperbolehkan untuk saling memberi sesuatu, dan keduanya dilarang keras mengambil kembali pemberiannya. ${ }^{25}$

Keenam, suami melecehkan keaiban jasmani atau rohani isteri. Suami yang baik adalah mereka yang dapat memberikan rasa tentram dan aman isterinya dari fitnah dan kejahatan orang lain, bukan malah menjadikan isteri depresi dan merasa tidak aman di rumahnya sendiri.

Ketujuh, suami meninggalkan isteri karena penyakit yang dideritanya. Seorang isteri pada saat menderita sakit, kondisi psikisnya mengalami penurunan. Dia membutuhkan seseorang yang bisa memberi semangat untuk selalu kuat dalam menghadapi penyakit yang dideritanya. Dia membutuhkan seseorang yang mampu memberikan ketenangan, pada saat jiwanya sedang rapuh karena penyalit yang dideritanya. Dalam keadaan seperti itu, kehadiran suami sangat dibutuhkan oleh isteri.

Kedelapan, suami menuduh isterinya melakukan zina tanpa adanya bukti yang jelas. Suami harus benar-benar berusaha menghindari terjadinya qadzaf, ${ }^{26}$ sebab perbuatan tersebut resikonya sangat besar. Jika suami menuduh isterinya berbuat zina, dan tuduhannya benar, maka isteri akan mendapatkan hukuman had. Tetapi sebaliknya, jika tuduhan suami terhadap isterinya tidak bisa dibuktikan, maka suami yang terkena sanksi had dan laknat Allah. ${ }^{27}$

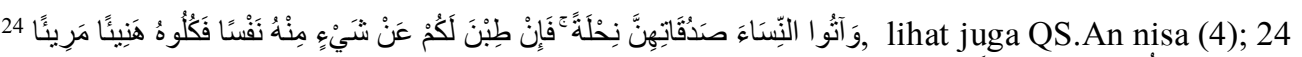

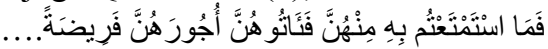
${ }^{25}$ Al Imam Al Hafidz Ibnu Hajar Asqolany, Fathul Bary Syarh Shahih Bukhari,Juz 9 (Riyadh, Maktabah Darus Salam, 1997), 22.

${ }^{26}$ Secara bahasa qadzaf bermakna melempar sesuatu, sedangkan menurut istilah yaitu menuduh orang lain secara terang-terangan melakukan zina tanpa disertai hujjah yang kuat dan jelas.
}

$$
\text { 27 }
$$


Kesembilan, suami dengan semena-mena menceraikan isteri tanpa alasan yang dibenarkan oleh agama. Jika suami isteri dalam menjalani hidup berumah tangga sudah tidak ada kecocokan dan kesepadanan prinsip dan pendapat, sehingga sering terjadi pertengkaran yang tak berkesudahan, maka Islam memberikan solusi melalui perceraian dengan baik-baik. Suami sebagai kepala rumah tangga tidak bisa serta merta menceraikan isterinya tanpa adanya alasan yang hak.

Kesepuluh, melakukan hubungan seksual yang terlarang baik melalui dubur maupun isteri dalam keadaan haid atau nifas. Islam mengibaratkan seorang isteri dengan sawah yang siap ditanami dengan jenis tanaman apapun dan cara tanam bagaimanapun. Artinya seoarng isteri, memang dipersiapkan oleh Allah untuk melayani kebutuhan seksual suami. Dalam melakukan hubungan tersebut Islam menyerahkan sepenuhnya kepada kedua belah pihak, tetapi ada rambu-rambu syariat yang tidak boleh diterjang yaitu menggauli isteri melalui duburnya, atau isteri dalam keadaan haid dan nifas.

Kesebelas, suami selalu mencari-cari kesalahan isteri. Tidak ada satupun manusia yang terhindar dari kekhilafan dan kesalahan. Karena berbuat salah dan khilaf adalah fitrah manusia. Saat ada yang berbuat salah, maka selayaknya kesalahan itu dimaafkan dan menjadi pembelajaran bagi mereka yang melakukannya. Suami idaman adalah mereka yang tidak selalu curiga pada isterinya apalagi mencari-cari keslahannya.

Kedua belas, suami menyuruh isteri melakukan kemaksiatan dengan melanggar larangan Allah. Seorang istri hukumnya wajib mentaati semua perintah suaminya, manakala perintah tersebut berupa kebaikan dan ketaqwaan. Tetapi jika perintah tersebut berupa kemaksiyatan dan kemusyrikan, maka isteri tidak boleh mentaatinya.

Ketiga belas, suami tidak adil dalam membagi waktu dan giliran pada isteriisterinya. Pada fitrahnya al Qur'an telah mensinyalir, bahwa seorang suami tidak mungkin berlaku adil pada isteri-istrinya. ${ }^{28}$

\section{KONSEP ISLAM DALAM PENYELESAIAN NUSYUZ}

\section{Solusi Penyelesaian Nusyuz isteri}

Hidup dalam rumah tangga sebagai suami isteri tidak lepas dari polemik dan konflik. Faktor penyebab terjadinya konflik bermacam-macam, bisa dari faktot internal

\footnotetext{
${ }^{28}$ QS. An Nisa'(4), 129
} 
suami isteri, atau faktor eksternal dari pihak ketiga. Penyebab konflik keluarga baik internal maupun eksternal mempunyai potensi yang sama merusak pondasi rumah tangga. Konflik internal yang sering memicu tidak harmonisnya hubungan suami isteri adalah nusyuz.

Terjadinya nusyuz bisa ditimbulkan oleh beberapa sebab, seperti tunt ut an yang diluar batas kewajaran atau ketidak puasan perlakuan dari salah satu pihak, seperti sikap suami yang tidak memperlakukan isterinya dengan baik, atau bisa juga sebaliknya kesalah pahaman istri dalam menyikapi hasrat dan keinginan pasangannya.

Aturan tentang tata cara penyelesaian nusyuz telah diat ur dalam Islam, baik yang terdapat dalam al Qur'an maupun dalam sunnah rasulullah. Jika nusyuz timbul dari pihak isteri baik berupa perkataan maupun perbuatan, seperti isteri bersikap sinis pada suami, menolak dengan terang-terangan dan tanpa alasan yang hak ajakan suami untuk melakukan hubungan seksual, berkata kasar pada suami, bersuara dengan nada tinggi saat dipanggil, dsb. maka Islam memberikan solusi terhadap suami untuk melakukan beberapa tindakan kongkrit sebagaimana difirmankan Allah dalam QS. 4; 34. Empat hal yang harus dilakukan oleh suami pada saat isterinya nusyuz, yaitu:

Pertama, menasehati. Ngambhul (madura), ngambek (jawa) adalah hal yang sering terjadi pada wanita. Salah satu ciri wanita yang sedang ngambek adalah enggan melaksanakan kewajibannya sebagai isteri, sikapnya acuh dan cuek terhadap lingkunagn sekitarnya. Kondisi seperti ini jika tidak segera disadari dan diatasi dapat menjadi pemicu terjadinya nusyuz.

Langkah awal yang harus dilakukan oleh suami menghadapi isteri yang sedang nusyuz adalah memberi nasehat dengan cara yang baik dan bijak. Kecerobohan dalam menasehati isteri yang sedang nusyuz berakibat fatal. Oleh karena itu, menasehati isteri yang sedang nusyuz harus ekstra hati-hati, sebab isteri yang sedang nusyuz kondisi psikisnya sangat sensitif. Hal yang harus dipahami oleh suami, bahwa isi nasehat bisa berupa ajakan untuk kembali taat kepada ajaran agama dengan melaksanakan kewajibannya sebagai isteri, dan menjauhi larangan Allah dengan tidak melakukah segala bentuk tindakan yang menyakiti dan membuat tersinggung suami, seperti keluar dari tempat tinggal bersama tanpa ada izin dari suami dan tanpa alasan yang jelas dan hak, bersikap kasar dan angkuh pada suami. 
Nasehat yang dilakukan oleh suami pada isterinya yang nusyuz merupakan bentuk tarbiyah suami sebagai kepala rumah tangga yang harus menjadikan isterinya sebagai wanita yang baik. Nasehat tersebut harus dilakukan dengan sikap bijak serta penuh kasih sayang. Manakala dengan cara tersebut tidak menjadikan isteri sadar dari nusyuznya, maka pihak suami harus memperingatkan isterinya dengan memberikan pemahaman bahwa tindakan nusyuznya tersebut melanggar aturan agama dan isteri dapat kehilangan hak-haknya. Jika dengan nasehat tersebut, si isteri sadar dan kembali menjalankan kewajibannya seperti biasanya, maka suami dilarang megungkit-ngungkit hal yang sudah pernah terjadi dan tidak boleh terus mencari-cari kesalahan isteri. ${ }^{29}$ Akan tetapi, manakala isteri tidak berhenti dari nusyusznya dengan nasehat, maka pihak suami dapat melakukan langkah kedua, yaitu terapi al hijr (pisah ranjang).

Kedua, Al hijr (pisah ranjang). Dalam hal ini tindakan al hajru dapat berupa perkataan ataupun perbuatan. Al hijr berupa perkataan seperti suami tidak mengajak bicara isterinya atau tidak merespon pembicaraan isteri, sedangkan al hijr berupa perbuatan seperti suami mengisolasi isteri dari tempat tidur dan juga tanpa adanya hubungan seksual dalam masa tertentu. Meskipun suami diperbolehkan melakukan al hijr, tetapi dia harus tetap memperhatikan etika dalam berkeluarga dan menjaga psikolgi isteri di hadapan anggota keluarga yang lain. Artinya tindakan tersebut harus dilakukan secara santun, tidak boleh ada rasa marah, melakukannya tidak secara frontal dan terangterangan sehingga diketahui oleh anggota keluarga yang lain terutama anak, sebab jika tindakan diketahui oleh anak, dapat mengganggu perkembangan psikologi dan mempengaruhi mind side anak terhadap orang tuanya. Etika lain yang harus dijaga kuat oleh suami adalah tidak bolehnya menceritakan tindakannya tersebut pada orang lain, karena dikhawatirkan orang tersebut malah mengolok-olok dan merendahkan derajat isteri, sehingga menjadikan isteri merasa terhina dan bisa saja membuat isteri semakin durhaka. Padahal terapi kedua ini dimaksudkan untuk menyadarkan isteri dari nusyuznya, bukan untuk merendahkan derajatnya apalagi merusak akhlak anak. Sebab jika anak mengetahui kedua orang tuanya tidak saling bertegur sapa dan tidak saling

\footnotetext{
${ }^{29}$ Amir Syarifuddin, Hukum Perkawinan Islam di Indonesia,... 192.
} 
merespon, maka mereka lambat laun akan menirunya Jumhur ulama memperbolehkan al hijr melalui ucapan dengan syarat tidak lebih dari tiga hari. ${ }^{30}$

Batas toleransi suami diperbolehkan melakukan tindakan al hijr dengan perbuatan pada isteri sampai dia menyadari kesalahannya, maksimal 4 bulan dan tidak diperbolehkan sampai melebihi batas waktu tersebut, sebab jika sampai lebih dari ketentuan tersebut, dikhawatirkan relasi suami dan isteri dalam keluarga semakin tidak kondusif. ${ }^{31}$

Ketiga, memukulnya. Manakala dengan terapi al hijr isteri masih saja tidak berubah dari nusyuznya, maka suami diperkenankan untuk memukul isteri, tetapi harus tetap memperhatikan persyaratan yang telah digariskan oleh syariat, yaitu: ${ }^{32}$

Pertama, dengan pukulan yang tidak membahayakan anggota fisik (ghair mubarrih), ${ }^{33}$ yaitu pukulan yang tidak sampai mematahkan tulang dan tidak melukai daging. Suami boleh memukul isterinya yang nusyuz dengan telapak tangannya dan itupun dengan kadar yang tidak menyakitkan dan pada tempat yang tidak membahayakan dan tidak boleh menggunakan alat yang dapat melukai isteri. Sebab jika sampai menyakiti dan melukai fisik isteri, sudah termasuk kategori tindakan kriminal dan pelaku dapat terkena sanksi pidana. Bahkan isterinya diperbolehkan menggugat cerai dan meng qishas suaminya. Maksud diperbolehkannya suami memukul isteri dalam hal ini adalah sebagai bentuk tarbiyah agar isteri sadar dan kembali pada aturan agama. Kedua, pukulan suami tidak melebihi 10 pukulan, sebab jika sampai lebih dari 10 pukulan dikhawatirkan suami tidak mampu mengendalikan diri, sehingga berakibat menyakiti pada istri.${ }^{34}$ Ketiga, pukulan yang dilakukan suami pada isteri mampu membuat isteri sadar dan tidak mengulangi perbuatan nusyuz lagi. Tetapi jika suami sudah mengetahui bahwa tindakan pemukulan kepada isteri yang sedang nusyuz tidak menjadikan dia sadar dan jera, maka sebaiknya tindakan pemukulan tersebut tidak

\footnotetext{
${ }^{30}$ Abi Abdillah bin Isma’il Bukhary, shahih Bukhory, juz 8, (Beirut, Dar Ibn Hazm, 2003), 19

31 Saleh bin Ghanim Al-Saldani, al-Nusyuz. Alih bahasa A. Syauqi Qadri, ( Jakarta: Gema Insani Press, 2004), 25.

${ }^{32}$ Abu Malik Kamal bin Sayyid Salim, Fiqhus Sunnah Lin Nisa', 734.

33 Zaini al-Din bin Abdul Aziz, Fath al-Mu'in, (Semarang: Pustaka Alawiyah, t.th), 110. Lihat juga Muhammad bin Umar Nawawi, 'Uqud al-Lujain, (Semarang: Pustaka Alawaiyah, t. th), 7. 34 عن ابي بردة الانصاري انه سمع رسول الله صلى الله عليه و سلم يقول : لا يجلد احد فوق عشرة اسواط الا فى حد من حدود الله. 
dilakukan. ${ }^{35}$ Meskipun menurut QS. 4; 34 diperbolehkan memukul isteri yang nusyuz, menurut pendapat as-Syafi'i, lebih baik untuk tidak melakukannya, karena tindakan tersebut adalah tindakan mulia dan termasuk tindakan pilihan Rasulullah.

Keempat, ber-tahkim (melalui jalur mediasi). Manakala semua tindakan yang telah dilakukan di atas tidak ada efek terhadap kesadaran isteri yang nusyuz, maka bisa dilakukan melalui jalur mediasi dengan cara mengangkat pihak ketiga sebagai penengah untuk menyelesaikannya. ${ }^{36}$ Apakah hubungan suami isteri tersebut akan dipisahkan atau tetap disatukan, tergantung hasil dari tahkim tersebut.

\section{Solusi Penyelesaian Suami Nusyuz}

Meskipun masih terjadi dabateble diantara para ulama tentang ada tidaknya nusyusnya suami, maka penulis berani menyatakan bahwa nusyuz juga bisa terjadi pada suami, sebagaimana tertera pada QS. 4, 128. Oleh karena itu, perlu ada tindakan kongkrit dalam menyelesaikan suami yang nusyuz tersebut. Ada beberapa tahap yang bisa dilaksanakan dalam hal ini. Pertama, melakukan analisis terhadap realita yang menyebabkan suami berbuat nusyuz. Tindakan tersebut harus dilakukan dengan ketelitian tingkat tinggi, agar tidak salah dalam menganalisis data yang sudah terkumpul dan tidak salah dalam membuat kesimpulan. Kesalahan dalam melakukan analisis akan berdampak pada cara yang akan diterapkan. Kedua, memberi nasehat pada suami dengan cara yang baik. Nasehat disini artinya melakukan komunikasi yang baik, agar suami luluh hatinya dan kembali menjalani hidup bersama secara harmonis. Ketiga, melakukan sulh (perdamaian). ${ }^{37}$ Berdamai adalah langkah yang tepat untuk ditempuh dengan suami yang nusyuz. Melalui langkah ini suami isteri harus sama-sama interospeksi dan tidak saling manyalahkan apalagi dendam satu sama lain.

Langkah yang mungkin kita anggap sedikit ekstrim adalah pendapat At-Thabari, dimana istri merelakan sebagaian haknya tidak dipenuhi oleh suami secara penuh dan berupaya berusaha memberikan perhatian dan pelayanan spesial kepada suaminya dengan harapan agar perasaan dan hati suami luluh dan kembali menjalani kehidupan

\footnotetext{
${ }^{35}$ Zaini al-Din bin Abdul Aziz, Fath..,110.

${ }^{36}$ Muhammad 'Ali as-Sabuni, Rawaiu al-Bayan Tafsir Ayat Al-Ahkam min Al-Quran, (Beirut - Mu'assisah Manahilul Irfan, 1980), 370-371

${ }^{37}$ QS. An Nisa' (4). 128
} 
rumah tangga bersama sebagaimana mestinya sesuai dengan kesepakatan dalam perjanjian nikah yang telah mereka buat. ${ }^{38}$

Keempat, gugat cerai (khulu'). ${ }^{39}$ Isteri diperbolehkan oleh agama mengajukan gugat cerai $\left(k^{\prime}\right.$ lu $\left.^{\prime}\right),{ }^{40}$ karena beberapa alasan diantaranya suami berbuat nusyuz. Langkah ini merupakan alternatif terakhir manakala perdamaian sudah tidak mungkin lagi ditempuh oleh kedua belah pihak. Gugatan cerai dengan jalan khulu'yang diajukan oleh isteri dapat dikabulkan oleh hakim, jika pihak suami diyakini benar-benar dapat membahayakan keselamatan anggota keluarga dan akhlak suami sudah jauh menyimpang dari ajaran agama dan tidak mungkin lagi diperbaiki.

Dari problem di atas dapat kita pahami, bahwa putusnya ikatan perkawinan antara suami isteri bisa saja dilakukan oleh suami dengan jalan talak dan dari pihak isteri melalui jalur gugat cerai (khulu'). Usaha istri untuk memutus ikatan perkawinan dari suaminya melalui uang tebusan disebut khulu'. Di sini terlihat bahwa Islam benar-benar sebagai agama solutif, yang memberikan solusi terhadap perkawinan yang sudah tidak mungkin dipertahankan karena adanya kedholiman yang dilakukan oleh suami. ${ }^{41}$

\section{Dampak hukum dari Nusyuz}

Setiap ada sebab mesti ada akibat, demikian halnya dengan tindakan nusyuz baik yang dilakukan suami atau isteri. Jumhur ulama sepakat bahwa apabila seorang isteri melakukan tindakan nusyuz maka ia tidak berhak mendapatkan nafkah, biaya perawatan dan pengobatan selama nusyuz sampai ia sadar kembali, hak pengasuhan terhadap anak menjadi gugur, karena dasar yang dijadikan alasan hak asuh anak jat uh pada isteri karena ia mempunyai sikap yang lembut dan akhlak yang baik, tetapi bagaimana mungkin isteri yang bertabiat buruk akan mengasuh dan memelihara anak-anaknya. Bahkan lebih jauh dari itu, manakala suaminya meninggal dunia, isteri yang nusyuz tidak berhak mendapatkan harta warisan suaminya. Sebab pemberian harta warisan didasarkan

\footnotetext{
${ }^{38}$ Abu ja'far Muhammad bin Jarir At Thabary, Tafsir Ath Thabary, Juz 9, (Jakarta, Pustaka Azam, 2009), 273

39 Perceraian dimana biaya perkara ditanggung oleh isteri atau upaya isteriuntuk melepaskan ikatan perkawinan dari suaminya dengan jalan memberikan iwadh (uang tebusan).

${ }^{40}$ QS. Al-Baqarah (2): 229

${ }^{41}$ Umar Haris Sanjaya dan Aunur Rahim Faqih, Hukum Perkawinan Islam, (Yogyakarta: GAMA MEDIA, 2017), 115.
} 
adanya ketaatan dan ketaqwaan, dan bagaima mungkin isteri yang tidak taat mendapatkan harta orang yang dibenci atau didurhakainya.

Tindakan Nusyuz dari suami terhadap istri berdampak pada sebagian hak istri tidak terpenuhi dengan layak. Sedangkan dampak yang diterima oleh anak diantaranya, beberapa hak anak tidak dipenuhi oleh ayahnya dengan baik, anak menjadi terabaikan dan hidup dalam keadaan memprihatinkan karena ayahnya mengabaikan kewajibannya. Kondisi seperti ini jika dibiarkan berlarut-larut akan berimbas terganggunya perkembangan psikis anak.

Merekonstruksi relasi harmonisasi dalam rumah tangga antara suami dan istri pada zaman modern seperti saat ini sangat penting dilakukan. Sehingga statement yang selama ini tumbuh di masyarakat, bahwa isteri hanya sebagai pihak yang tidak mempunyai peran penting dalam rumah tangga, dan pandangan miring suami yang menganggap isteri hanya sebagai konco mburi yang kemudian meposisikannya sebagai bagian yang tidak penting dalam rumah tangga, akan berubah bahwa isteri mempunyai posisi dan peran yang penting dalam membangun keluarga yang sejahtera dan harmonis. Sehingga posisi isteri dalam keluarga tidak lagi sebagai konco mburi dan sub ordinat, tetapi isteri sebagai mitra sejajar suaminya. ${ }^{42}$

Allah menjadikan posisi suami sebagai bagian yang tak terpisahkan dari isteri, demikian juga sebaliknya isteri sebagai bagian yang sangat penting bagi suami. Keduanya saling membutuhkan sehingga jika salah satu tidak ada maka kehidupan dalam rumah tangga tidak sempurna dan hidup seakan tidak sempurna dan tidak bermakna. Firman Allah dalam QS. 2:187 ${ }^{43}$ dan QS. 4; $19 .^{44}$

Dalam sebuah hadis juga disebutkan:

$$
\begin{aligned}
& \text { عَنْ أَبِي هُرَيْرَة رَضِيَ اللَّهُ عَنْهُ قَالَ: قَالَ رَسُول اللَّه صَلَّى الله عَلَيهِه وَسَلَّمَ : أَكْمَل الْهُوْْمِنِينَ إِيمَانًا }
\end{aligned}
$$

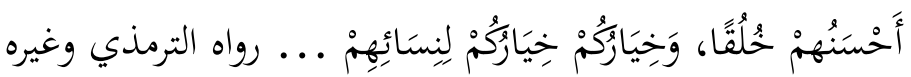

\footnotetext{
${ }^{42}$ Zaitunah Subhan, Tafsir Kebencian ..., . 68-72.

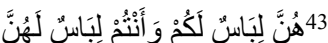

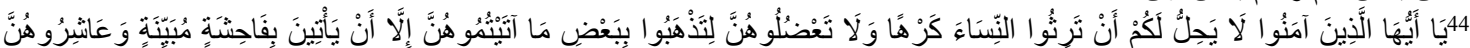

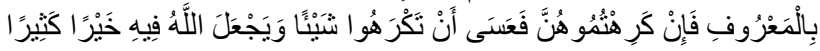


Dari Abu Hurairah ra, Rasulullâh saw telah bersabda, "Paling sempurnanya keimanan seorang mukmin adalah yang terbaik perangainya dan sebaik-sebaik kamu adalah orang yang paling baik kepada istrinya." 45

Pemahaman ulang terhadap konsep nusyuz sebagaimana dijelaskan di atas semuanya bermuara pada satu tujuan yaitu terbentuknya keluarga yang harmonis dan sejahtera penuh dengan cinta dan kasih jauh dari tindakan kekerasan dan diskriminatif.

\section{KESIMPULAN}

Nusyuz adalah konflik yang terjadi dalam relasi suami istri dalam rumah tangga, yang bisa disebabkan baik dari pihak isteri maupun suami dengan beberapa faktor yang melatar belakanginya, seperti adanya kesalahan yang dilakukan oleh suami baik berupa perkataan maupun perbuatan atau sebaliknya kesalahan dari pihak istri.

Islam telah mengatur tatacara dalam menyelesaikan tindakan nusyuz istri maupun suami. Terdapat beberapa tindakan dalam menyikapi isteri nusyuz, yaitu: menasehati dengan bijak, al hijr (pisah ranjang dan tidak melekukan hubungan seksual), memukulnya tetapi tidak membahayakan dan menyakitkan, bertahkim (mengangkat hakam) untuk menyelesaikan kasusnya. Sedangkan solusi yang ditawarkan oleh islam dalam mengatasi suami yang nusyuz adalah; pertama istri harus berupaya mengetahui latar belakang nusyuznya suami, kedua, menasehati suami secara baik agar dapat memahami sikapnya dengan melakukan perenungan berfikir dan berefleksi, ketiga, berdamai dengan suami, ke-empat, mengajukan gugatan perceraian dengan jalan khulu'.

Dampak dari isteri nusyuz adalah hilangnya sebagian dari hak-hak isteri dan gugurnya sebagian kewajiban suami kepada isteri, seperti kewajiban memberi nafkah, menyediakan tempat kediaman bagi isteri, biaya perawatan dan pengobatan. Sedangkan suami nusyuz berakibat pada isteri dan juga anak. Istri dan anak menjadi terlantar, hak anak dan isteri tidak terpenuhi, berdampak negatif pada psikhis isteri dan anak, tidak berlaku kewajiban istri terhadap suami dan istri dapat mengajukan gugatan perceraian dengan jalur khulu’.

\footnotetext{
${ }^{45}$ HR. At-Tirmidzi, 3/466; Ahmad, 2/250 dan Ibnu Hibban, 9/483. Hadits dinyatakan shahih oleh Imam at-Tirmidzi, Ibnu Hibban dan Syaikh al-Albani
} 


\section{DAFTAR PUSTAKA}

Abidin, Slamet dan Aminuddin. Fiqh Munakahat, jilid 1\&2, Bandung, Pustaka Setia, 1999.

ad-Dimasyqi, Imam Taqiyuddin Abu Bakr ibn Muhammad al-Husain, Kifayat alAkhyar, Juz, II, Beirut, Dar al Kitab al Ilmiyah, 1995.

Ahmad al-Qurtubi, Abu Abdillah bin, Al-Jami'i Ahkam al-Qur'an, Juz, III, Bairut, Dar al-Fikr, t.th.

Al-Saldani, Saleh bin Ghanim al-Nusyuz. Alih bahasa A. Syauqi Qadri, Jakarta: Gema Insani Press, 2004.

Alu Syaikh, Abdullah bin Muhammad bin 'Abdurrahman bin Ishaq. Tafsir Ibnu Katsir Jilid 2 terj. Abdul Ghoffar E.M. Bogor: Pustaka Imam Asy-Syafi’i, 2004.

Asqolany, Al Imam Al Hafidz Ibnu Hajar Fathul Bary Syarh Shahih Bukhari,Juz 9, Riyadh, Maktabah Darus Salam, 1997.

As-Sabuni, Muhammad 'Ali, Rawaiu al-Bayan Tafsir Ayat Al-Ahkam min Al-Quran, Beirut - Mu'assisah Manahilul Irfan, 1980.

At Thabary, Abu Ja'far Muhammad bin Jarir, Tafsir Ath Thabary, Juz 9, Jakarta, Pustaka Azam, 2009.

---------- , Tafsir Ath-Thabari, Juz 8, Jakarta, Pustaka Azzam, 2008.

Aziz, Zaini al-Din bin Abdul Fath al-Mu'in, Semarang: Pustaka Alawiyah, t.th.

Baqi, Muhammad Fuad Abdul, Al-Mu'jamul Mufahras li alfadz al-Quran al-Karim, Bandung: CV. Diponegoro, t.th.

Bukhary, Abi Abdillah bin Isma'il shahih Bukhory, Juz 8, Beirut, Dar Ibn Hazm, 2003. Jalaluddin al-Mahalliy dan Jalaluddin as-Suyuthi. Tafsir Jalalain, Juz. I, Dar al-Ihya' alKutub Al-Arabiyyah Indonesia, tth.

Manzur, Ibn. Lisan al-Arab, Kairo: Dar al-Ma"earif, t.th.

Narwoko, J. Dwi dan Bagong Suyanto, Sosiologi: TeksPengantar dan Terapan, Jakarta: Kencana, 2007.

Nawawi, Muhammad bin Umar 'Uqud al-Lujain, Semarang: Pustaka Alawaiyah, t. th.

Sabiq, Sayyid. Fiqh Sunnah, Jilid II, Madinah: Al-Fatkh Li i'lamil Araby, 1990.

Sanjaya, Umar Haris dan Aunur Rahim Faqih, Hukum Perkawinan Islam, Yogyakarta: GAMA MEDIA, 2017.

Subhan, Zaitunah. Tafsir Kebencian: Studi Bias Gender dalam Tafsir Al-Qur'ān, Cet. 1, Yogyakarta: LKiS, 1999. 
Al-‘Adalah: Jurnal Syariah dan Hukum Islam

e-ISSN: 2503-1473

Hal. 194-215

Vol. 4, No. 2, Desember 2019

Syarifuddin, Amir. Hukum Perkawinan Islam di Indonesia, Antara Fiqh Munakahat dan Undang-Undang Perkawinan, Jakarta: Kencana. 2006. 